\title{
Innovations in Russian Industries: Conditions for Implementation and Impact on Competitiveness ${ }^{*}$
}

\author{
Igor Gurkov ${ }^{* *}$
}

Based on the result of a survey of 1500 Russian industrial companies we not only clarified the intensity of particular innovations but also interconnections between technological and managerial innovations. We also determined the institutional factors that affect the intensity of particular innovations, i.e. presence of foreign ownership, openness of local markets to international competition and inclusion of companies into large corporations to/that foster innovations. At the same time, the rigidity of organizational structures and inertia of local production networks put serious limitation on radical product and technological innovations. The further development of Russian industries will largely depend on organizational flexibility of corporations and on increasing mutual trust within local business networks.

Unter Nutzung der Ergebnisse einer Umfrage unter 1500 Industrieunternehmen werden nicht nur die Intensität von spezifischen Innovationen, sondern auch die Zusammenhänge zwischen Technologie- und Managementinnovationen nachgewiesen. Weiterhin wurden auch die institutionellen Faktoren bestimmt, die diese Innovationen beeinflussen wie das Vorhandensein ausländischen Eigentums, die Öffnung des Marktes zur internationalen Konkurrenz und die Einbindung von Firmen in große Unternehmen, um Innovationen voranzutreiben. Gleichzeitig erschweren rigide Organisationsstrukturen und lokale Produktionsnetzwerke radikale Produkt- und Technologieinnovationen immens. Die zukünftige Entwicklung der russischen Industrien wird weitgehend von der organisationellen Flexibilität der Unternehmen und dem wachsenden gegenseitigenVertrauen innerhalb lokaler Handelsnetzwerke abhängen.

Keywords: innovations, competitiveness, organizational design, strategic architecture

\footnotetext{
Manuscript received: 16.02.05, accepted: 29.07 .05 (1 revision)

** Igor Gurkov, born 1965, Professor, Head of the Center for Organisational Studies, State University, Higher School of Economics, Moscow. Main research interests: Corporate strategies, organisational design, management innovation, competitiveness. Corresponding address: igor_gurkov@yahoo.com
} 


\section{Introduction}

The present tasks of national development may be translated as strengthening of national competitiveness. This task is not limited just to the state economic policy measures or the building of institutions. In its essence, national competitiveness is manifested in the activities of national companies that supply consumers with competitive goods and services.

Macroeconomic growth in key economic sectors observed in Russia in 19992004, at first glance, bears witness to the strengthening of national competitiveness. At the same time, paradoxically, economic growth results in enhanced complexity of enterprises' development. Indeed, a Russian firm no longer simply aims at "surviving" vis-à-vis its "collapsing" counterparts. Nowadays the major objective is to use the emerging market opportunities quicker than its competitors do $^{1}$. Additionally, seizing such opportunities is becoming increasingly difficult.

On the one hand, the growth of incomes of population and the improvement of financial positions of companies lead to stricter requirements of consumers with respect to quality of commodities and services. Both consumer goods and investment products are equally concerned. The greater "capriciousness" of consumers forces companies to develop new goods and to search for new forms of marketing.

On the other hand, technological solutions of the 1960-70s that form the basis of the fixed assets of the key Russia's industrial sectors have virtually exhausted their potential. Therefore, an objective necessity of mastering technologies that are qualitatively new, at least for Russia, is arising.

Discussing product and technological innovations and "new approaches" in management systems, the issue of competitiveness is quite naturally translated into structure and forms of Russian firms' innovative activities.

\section{Theory of Industrial Innovations - Relevant Issues and Unresolved Problems}

During the past 40 years of research and practices indissoluble links between technological, organizational and product innovations became evident (Myers/Marquis 1969; Normann 1971; Damanpour 1987). Moreover, normative management literature directly postulates the integration of technological, market and organizational changes as the ultimate way to improve competitiveness at firms' and industries' level (Teece 1987; Doz/Thanheiser 1993; Tushman/Anderson 1997; Tidd/Bessant/Pavitt 2001).

1 "Strengthening position in domestic markets" became the ultimate goal of Russian CEOs, moving from the forth rank in 2000 towards the first place in 2002 (see Gurkov 2004: 425). 
However, the relationship between particular types of innovations is unclear. The simplest form of a typology of innovations is a distinction between product innovations (changes in what is produced and offered to consumers) and process innovations (changes in how it is achieved). Product innovations are said to have a market focus and are primarily customer driven, while process innovations have an internal focus and are primarily efficiency driven (Utterback/Abernathy 1975). Myriads of empirical studies were conducted to trace the relationship between product and process innovation, using the "product cycle model" (Abernathy/Utterback 1978), and the "reverse product cycle model" (Barras 1986, 1990). However, it was suggested that "empirical studies that focused on dynamics nature of product and process innovations have produced murky results because not enough is yet understood about the fundamental difference between product and process innovations" (Gopalakrishnan, Bierly, Kessler 1999: 149). A part of this difference (lies)originates in a very complex, "matreshka" structure of process innovation.

Indeed, at the first "level" of analysis process innovations could be subdivided into:

- technological and

- managerial (administrative) innovations.

The distinction between administrative and technological innovations reflects the more general distinction between the social structure and technology (Evan 1966). Technological innovations mean the use of new products, processes or technologies for the manufacturing of goods or provision of services. Technological innovations can be said to reflect changes in activities with respect to inanimate matter. Administrative innovations concern changes in organizational structures and administrative processes ${ }^{2}$. These innovations always reflect changes in relations between people. Therefore, we can say that administrative (managerial) innovations always mean changes in social practices.

The second "level" of distinction concerns administrative innovations as such. Managerial innovations can be subdivided into two key types:

- changes in managerial techniques, i.e. changes in the forms of activities in finance, marketing, personnel management, etc.;

- organizational innovations, i.e. new forms of differentiation, integration and control of activities.

For example, the use of a new questionnaire for the selection of new candidates for a vacancy represents an innovation in the sphere of management technique, while the establishment of a special selection group to deal exclusively with the

2 See Daft (1978); Damanpour/Evan (1984); Damanpour (1987). 
testing of candidates within HR Department of a company will mean an organizational innovation.

At this point we already made a step further from the major publications on organizational innovations (Damanpour 1991; Frambach/Schillewaert, 2002). However, we must move "deeper" and point out that organizational innovations can also be subdivided into two types, i.e. intra-firm and inter-firm innovations. Intra-firm organizational innovations (let's call them OI-1) are connected with the creation of new forms of differentiation, integration and control of works within a firm. The above-mentioned example of a Personnel Selection Group represents an intra-firm innovation. Inter-firm innovations (to be referred to as OI-2) change relations between firms, both within value chains (i.e. relations between suppliers and consumers, contractors and customers) and within a group of firms connected by common ownership and control. If a firm commissions a special recruiting agency to conduct testing of candidates instead of establishing a special unit staffed by its own employees, it will mean an interfirm innovation. The distinction between intra-firm and inter-firm innovations is obvious for researchers with the background in industrial organization (Brocas 2003), but usually escapes the attention of researchers with the background in technology management.

Meanwhile, this distinction between so-called OI-1 and OI-2 is crucial for determining the impact of innovations on firm's performance. Indeed, if a new unit within a firm is established successfully, the firm itself will get all the benefits, i.e. the enhanced quality of selection of potential employees. If this task is delegated to an independent contractor, these two firms will share the potential positive effects. This example demonstrates that intra-firm innovations are aimed at the internal organizational cost reduction. Inter-firm innovations always involve redistribution of value between different economic players.

As a result of our speculations, we identified five types of innovations:

- product innovations;

- innovations in technological processes;

- innovations in management technologies;

- organizational intra-firm innovations (OI-1);

- organizational inter-firm innovations (OI-2).

The goals of the study thus were formulated as follows:

- to identify main types of innovations with respect to a firm's activities;

- to determine the spread of particular innovations in key sectors of Russia's industry by using methods available to us;

- to depict key internal links, moderators as well as possible external factors that affect innovative process. 
All the above-mentioned individual tasks were subordinated to the general objective of defining the configuration of a firm's innovative activities that would create preconditions for a breakthrough in the level of competitiveness.

\section{Empirical Basis for the Observation of Innovative Practices of Russian Companies}

The observation of innovative processes at firms' level encounters significant difficulties. The state statistics in Russia only report technological innovations ${ }^{3}$; innovations in goods and services are much less precisely reported by quality supervising bodies. As far as managerial innovations as such are concerned, there are no systematic statistics in this sphere at all. Taking into account these complexities, we undertook an independent large-scale survey in Russian enterprises in August-December 2002. An English version of the questionnaire used in this survey is presented in Appendix 1.

The questionnaire was developed through a series of studies in 1997-2002. In 1997, we implemented a pilot survey of 121 testing the questions about the competitiveness (Question 20). In 1998, we surveyed 735 CEOs of several industrial companies. In that study, we tested an instrument on "measures to improve performance" which included 18 innovative and routine items measured on a 2-pole 5-point scale. In 2000, we implemented another survey of 742 where we distinguished between innovations and routine measures. In this survey, the list of innovation measures contained eleven types of innovations and a 4-point scale was used. For the survey in 2002, we expanded the list of innovations towards 16 types (Question 22). In designing and polishing this instrument we followed the established tradition of measuring innovativeness by assessing managers' reflection on firm's practice (Maital, 2000). Such an approach removes doubts about the real meaning of "radically new" things in firms activities - if they are perceived as "radically new" by managers, the managers behave accordingly, i.e. face the uncertainty, expand their knowledge base and the repertoire of work methods etc.

The reliability (Cronbach's alpha) for the scale on competitiveness (Question 20) was 0,8112 ; the reliability (Cronbach's alpha) for the scale on innovations (Question 22) was 0,8409.

The survey was carried out in two steps. First, a part of the questionnaire was filled by 1123 CEOs in July-August 2002. In October-November $200270 \%$ of those CEOs (exactly, 784 persons) filled the second part of the questionnaire ${ }^{4}$.

\footnotetext{
See Vasin/Mindeli (2002). The same is true for observations of innovations in the European Union - see OECD (2002).

4 Questions of the second part of the questionnaire are marked by * in Appendix 1. Questions from 1 to 10 were reproduced in the both parts of the questionnaire.
} 
The survey itself was administered by the Government's Information Agency. A local official of the agency personally delivered the questionnaires to a CEO, made a short presentation of the questionnaires and after two weeks collected the same. Thus, the response rate was almost $100 \%$, and the personal involvement of a CEO in the survey was asserted ${ }^{5}$. The questionnaires were returned in closed and sealed envelopes to protect confidentiality of the answers to the local authorities.

The companies selected for the survey satisfied the following criteria:

- they represented all the main Russian industries;

- they were situated in all 88 Russian "federative subjects" (oblast or autonomous republic);

- they included both privatized and newly created companies;

- they included companies under different ownership arrangements.

\section{Interrelations between Types of Innovations: Initial Hypotheses}

As the "conventional" innovation theory was unable to stipulate the relationship between the distinguished types of innovations, we made a series of propositions based on a common "business logic", presented in normative publications (Doz/Thanheiser 1993; Tushman/O'Reilly III 1997) and in numerous business cases on "successful innovative companies". In general, interrelations between the five identified types of innovations in the activities of a firm may be presented as follows:

1) While trying to keep the existing or to get new customers a firm develops and introduces product innovations (see Weiss 2003);

2) New products can rarely be manufactured without changes in technology; therefore, product innovations to a large extent "provoke" technological innovations, though this relation is not always straightforward";

3) Production and sale of new products might require changes in marketing or personnel management. Besides, the objective of raising finance for new projects provokes changes in financial management and accounting systems. Hence, the relations here are virtually straightforward;

5 Technically, the response rate was greater than $100 \%$. Because of the interest of the government agency to get as much information as possible and the willingness of CEOs to provide information to the Federal Government the second part of the questionnaire was filled by 1093 CEOs, so the total number of participating enterprises was 1442. In this article, we excluded answers from 319 CEOs who participated in the second stage of the survey only.

6 Sometimes, the biggest technology changes are required for maintaining quality of the existing products. 
4) Changes in the system of operations due to innovations in production technologies and management forms require new procedures for the division of labour, i.e. innovations in the internal organization of a firm.

5) The development of new products and technologies could lead to the revision of the range of the firm's business partners, as well as to changes in the ratio between "internal" and "contracted" works. Therefore, product and technological innovations provoke inter-organizational innovations.

The above-listed relations characterize both static and dynamic systems. Moreover, we believe that the change in the intensity of one type of innovation, rather than innovations as such, provokes changes in the intensity of innovations of another type. Therefore, we can formulate the following hypotheses:

- Hypothesis 1 - changes in the intensity of technological and product innovations affect the intensity of managerial innovations.

- Hypothesis 2 - innovations in managerial techniques provoke organizational innovations of the first type (OI-1).

- Hypothesis 3 - the growth in the number of product and technological innovations leads to the higher probability of organizational innovations of the second type (OI-2).

The abovementioned hypotheses may be presented as a simple functional diagram (see Figure 1).

\section{Innovations in the Institutional Context}

The above-formulated hypotheses are based on the premise of a deliberate and free choice of the directions of a firm's activities. This premise rarely works in the real business world; most innovations are forced. It particularly concerns managerial technologies. Here, owners who deliberately standardize managerial processes in enterprises under their control might exert pressure. Business partners who require "coinciding" procedures and methods of activities might also exert pressure. Other stakeholders, such as regulatory authorities who require that a firm should "operate as everyone else" might also be a source of pressure.

Therefore, the role of the institutional context, i.e. the degree of a firm's dependence on its key stakeholders, becomes extremely important. Hence, the above-formulated hypotheses of the "innovative relations of an absolutely independent firm" might be refuted after being tested in practice. Moreover, we can formulate the Hypothesis 4 - there is a certain optimal structure of external pressure that maximizes the intensity of a firm's innovative activities. 
Figure 1. Interconnections between managerial and technological innovations

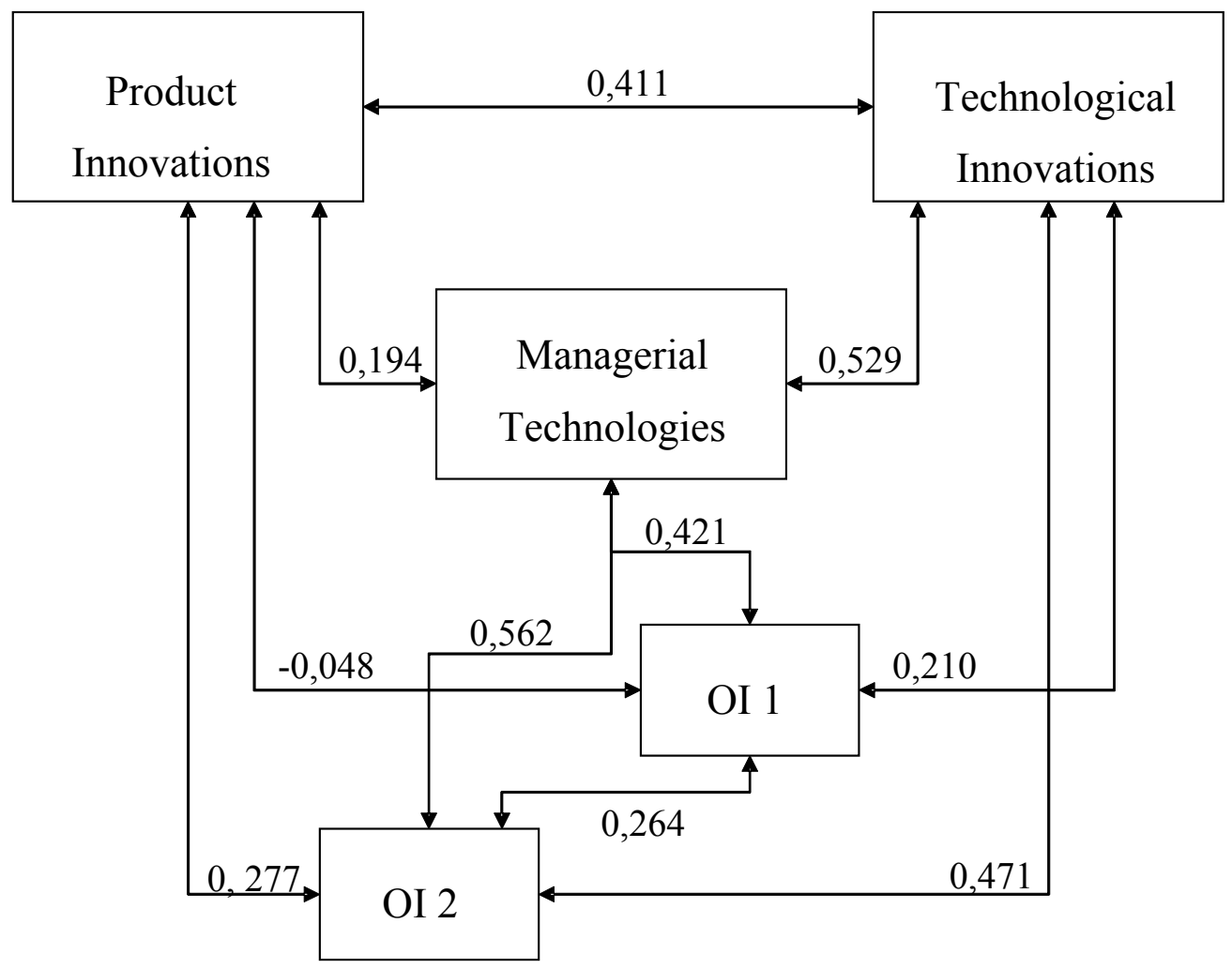

\section{The General Intensity of Product and Technological Innovations}

Assuming that product and technical innovations are primary causes of changes in other spheres of firms activities (Hypotheses 1 and 3), we started our analysis with the identification of the general intensity of such innovations.

Table 1. The General Intensity of Technological and Product Innovations (Percentage of Enterprises)

\begin{tabular}{|l|c|c|c|c|}
\hline & $\begin{array}{c}\text { Launching of } \\
\text { radically new } \\
\text { types of } \\
\text { products in the } \\
\text { current sphere } \\
\text { of activities }\end{array}$ & $\begin{array}{c}\text { Launching of } \\
\text { production of } \\
\text { goods (services) } \\
\text { in the new } \\
\text { sphere of } \\
\text { activities }\end{array}$ & $\begin{array}{c}\text { Launching of } \\
\text { technologies } \\
\text { processes) that } \\
\text { are new for the } \\
\text { firm }\end{array}$ & $\begin{array}{c}\text { Launching of } \\
\text { new methods } \\
\text { of quality } \\
\text { control (ISO } \\
\text { 9000-14000) }\end{array}$ \\
\hline Did not happen & 22.7 & 38.6 & 21.2 & 41.3 \\
\hline $\begin{array}{l}\text { To the smallest } \\
\text { extent }\end{array}$ & 14.6 & 19.9 & 23.0 & 19.2 \\
\hline $\begin{array}{l}\text { To a certain } \\
\text { extent }\end{array}$ & 39.0 & 29.4 & 40.9 & 22.5 \\
\hline To a large extent & 23.6 & 12.2 & 15.0 & 17.0 \\
\hline
\end{tabular}


Table 1 shows that launching of new products and technologies occurred on quite a large scale; overall, more than a half of enterprises launched new products, while more than $40 \%$ of enterprises took certain efforts to launch new technologies. At the same time, we should not overestimate the real novelty of launched products and technological solutions. In our sample, new technologies were simply copied in $30 \%$ of the cases, and new products were copied from competitors in $50 \%$ of the cases.

With regard to managerial technologies, we should point to a high intensity of innovations in accounting and remuneration practices. As far as organizational innovations are concerned, there were transformations of the internal organizational structure and changes in the range of business partners (see Table 2).

Table 2. Intensity of Innovations in Managerial Technologies and a Firm's Organization

\begin{tabular}{|c|c|c|}
\hline Type of innovations & $\begin{array}{c}\text { Level of application of } \\
\text { innovations }\end{array}$ & $\begin{array}{c}\text { Percentage of } \\
\text { enterprises }\end{array}$ \\
\hline \multicolumn{3}{|c|}{ Managerial technologies } \\
\hline \multirow{4}{*}{$\begin{array}{l}\text { Introduction of Western accounting } \\
\text { standards }\end{array}$} & Did not happen & 47,3 \\
\hline & To the smallest extent & 25,5 \\
\hline & To a certain extent & 20,3 \\
\hline & To a large extent & 7,0 \\
\hline \multirow{4}{*}{$\begin{array}{l}\text { Introduction of new managerial } \\
\text { accounting systems }\end{array}$} & Did not happen & 9,5 \\
\hline & To the smallest extent & 20,5 \\
\hline & To a certain extent & 40,6 \\
\hline & To a large extent & 29,4 \\
\hline \multirow{4}{*}{ Application of new financing methods } & Did not happen & 32,4 \\
\hline & To the smallest extent & 27,6 \\
\hline & To a certain extent & 29,7 \\
\hline & To a large extent & 10,2 \\
\hline \multirow{4}{*}{$\begin{array}{l}\text { Application of new forms and sources } \\
\text { of personnel recruitment }\end{array}$} & Did not happen & 33,5 \\
\hline & To the smallest extent & 37,5 \\
\hline & To a certain extent & 24,9 \\
\hline & To a large extent & 4,1 \\
\hline \multirow{4}{*}{$\begin{array}{l}\text { Application of new methods of } \\
\text { personnel appraisal }\end{array}$} & Did not happen & 29,8 \\
\hline & To the smallest extent & 33,5 \\
\hline & To a certain extent & 29,4 \\
\hline & To a large extent & 7,4 \\
\hline \multirow{4}{*}{$\begin{array}{l}\text { Introduction of new remuneration } \\
\text { systems }\end{array}$} & Did not happen & 10,5 \\
\hline & To the smallest extent & 27,9 \\
\hline & To a certain extent & 42,9 \\
\hline & To a large extent & 18,7 \\
\hline \multicolumn{3}{|c|}{ Intra-organizational innovations (OI-1) } \\
\hline \multirow[t]{2}{*}{ Establishment of new structural units } & Did not happen & 37,6 \\
\hline & To the smallest extent & 19,9 \\
\hline
\end{tabular}




\begin{tabular}{|l|c|c|}
\hline \multirow{4}{*}{ Spin-off of subsidiaries } & To a certain extent & 28,1 \\
\cline { 2 - 3 } & To a large extent & 14,5 \\
\hline \multirow{4}{*}{ Inter-organizational innovations (OI-2) } \\
\cline { 2 - 3 } & Did not happen & 68,1 \\
\cline { 2 - 3 } & To the smallest extent & 12,7 \\
\hline \multirow{4}{*}{ Acquisition of new enterprises } & To a certain extent & 12,6 \\
\hline \multirow{3}{*}{$\begin{array}{c}\text { Acquaintance with new Russian } \\
\text { business partners }\end{array}$} & To the smallest extent & 6,6 \\
\cline { 2 - 3 } & To a certain extent & 87,6 \\
\cline { 2 - 3 } & To a large extent & 4,8 \\
\hline \multirow{4}{*}{ Acquaintance of new foreign partners } & Did not happen & 4,5 \\
\cline { 2 - 3 } & To the smallest extent & 3,1 \\
\cline { 2 - 3 } & To a certain extent & 15,8 \\
\cline { 2 - 3 } & To a large extent & 23,3 \\
\cline { 2 - 3 } & Do the smallest extent & 44,8 \\
\cline { 2 - 3 } & To a certain extent & 16,2 \\
\cline { 2 - 3 } Development of new distribution & To a large extent & 49,4 \\
\hline forms and channels & Did not happen & 22,5 \\
\cline { 2 - 3 } & To the smallest extent & 22,7 \\
\cline { 2 - 3 } & To a certain extent & 5,4 \\
\cline { 2 - 3 } & To a large extent & 18,0 \\
\hline
\end{tabular}

\section{Interconnectedness between Different Types of Innovations}

To start our analysis we constructed a model of interconnectedness between product, technological and managerial innovations using correlation analysis (see Figure 2).

Our analysis revealed various levels of connections between different types of innovations. First, the correlation between product and technological innovations turned out to be high in the general case (correlation coefficient of 0,411 ); i.e. the development of marketing and production strategy takes place in a single complex in almost $50 \%$ of enterprises. Technological innovations and innovations in managerial technologies demonstrated an even higher level of connections (correlation coefficient of 0,529$)$.

We would like to remind that innovations in the sphere of accounting and remuneration dominated in managerial technologies. Here, the meaning of connections is also quite evident. On the one hand, the objectives of implementing new technical processes in more than $50 \%$ of companies are connected with the fine-tuning of business planning systems that are based on better cost accounting. On the other hand, the introduction of radically 
new technologies usually provides problems for employees. The redesign of remuneration systems aims to overcome the resistance to new technologies and to facilitate the mastering the new methods of work.

Figure 2. Interconnections between Product, Technological and Managerial Innovations

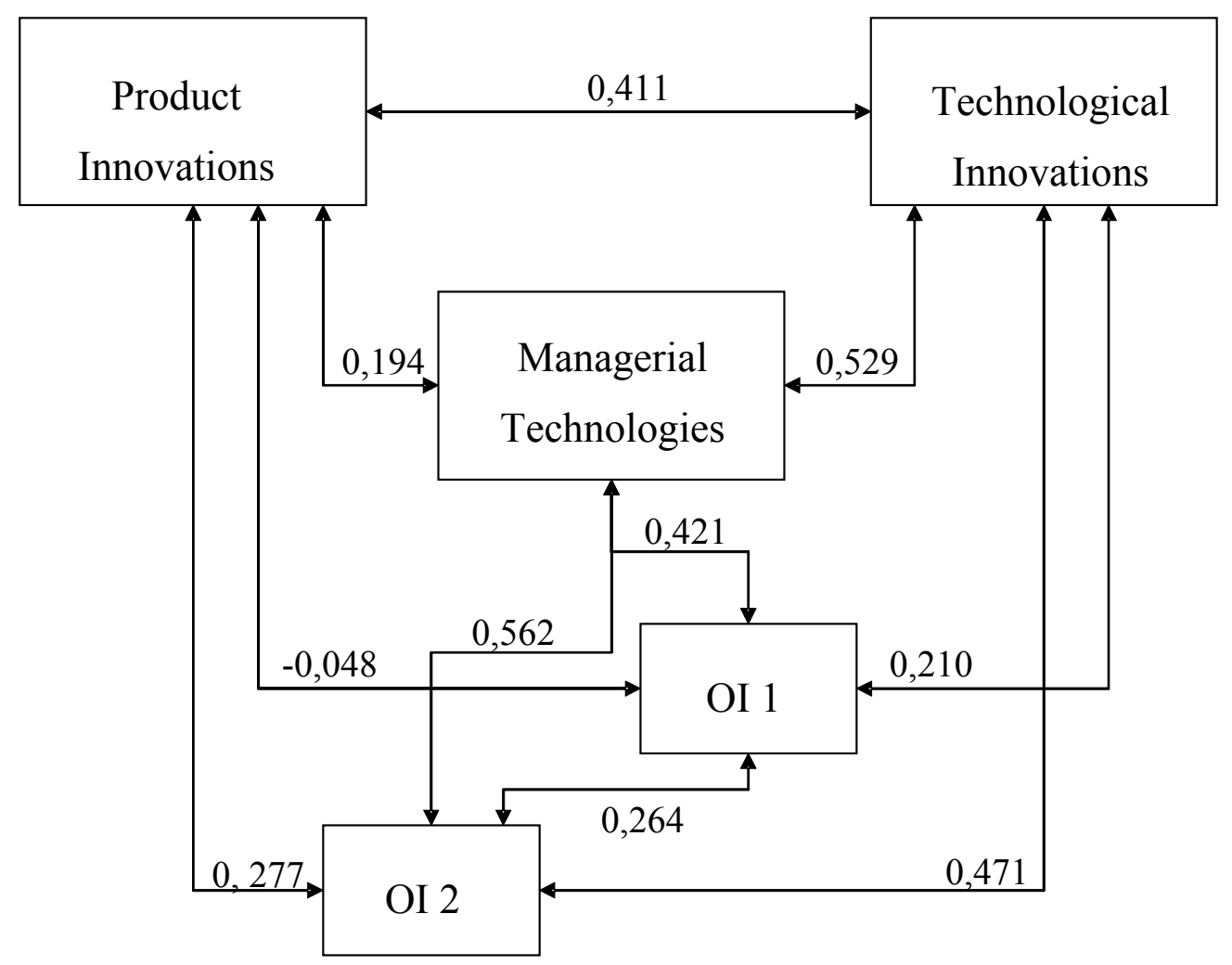

We also see the strong links between technological innovations and interorganizational innovations. We should remind that the most popular interorganizational innovation was the "change in the range of Russian business partners" (see Table 2). At the first glance, it might testify to the high market dynamism and the availability of alternative suppliers in Russia. However, the situation appears less bright after a thorough analysis. Indeed, the existence of such strong links means that any substantial improvement in technology inevitably removes a Russian firm from the circle of its traditional partners that can no longer ensure deliveries that meet the new quality standards of the firm. Objectively, such inertia is a serious obstacle to radical technological innovations. The same is true concerning the close interconnectedness between managerial technologies and inter-organizational innovations. The fine-tuning of the managerial accounting system appears to lead to a reassessment of the existing range of suppliers. 
We did not expect a very close connection between product innovations and intra-organizational changes. However, the discovery of a negative (albeit not statistically significant) correlation was a bit shocking. It means that the organizational restructuring happens in isolation from innovations in product programs.

However, the most interesting result was the close connection between managerial innovations and the transformation of the firm's value chain (new distribution channels, new local and foreign partners, acquisition of other companies). This relationship may be explained in both ways - a Russian company which embarks on a radical transformation of management techniques looks towards "corresponding" partners, or the new partners superimpose changes in management processes. In both cases we figured out an issue completely missing in the current studies on determinants for innovation adoption.

Our analysis confirmed that there was a close interconnection between individual types of innovative activities of a firm. Product and technological innovations, management systems and the structure of a firm's foreign relations transform to a large extent as a single complex. At the same time, organizational structures of Russian industrial firms do not follow the logic of product innovations.

As the sample size of the sample enabled us to make cross-sectional comparisons, we split all cases into two sub-samples. One sub-sample embraced companies of industries where we found a low level of product innovations (extracting of natural resource, energy, timber). The second sub-sample included companies of industries with a relatively high level of product innovations (chemicals, machine-building, electronics, food and textiles). We ran correlation analysis for the types of innovations separately for each of the sub-samples, but found no noticeable differences in the types of relationship between the examined variables.

\section{Institutional Pressure: Incentives and Obstacles to Innovative Activities of Enterprises}

We assumed that the institutional environment could significantly affect the processes of innovative development (Hypothesis 4). In order to test this assumption we assessed the connection between the institutional factors and the intensity of particular innovations (see Table 3). 
Table 3. Correlations between Institutional Parameters in the Firm's Environment and Intensity of Innovative Activities (Correlation Coefficients)

\begin{tabular}{|l|c|c|c|c|c|}
\hline & $\begin{array}{c}\text { Product } \\
\text { Innovations }\end{array}$ & $\begin{array}{c}\text { Technological } \\
\text { Innovations }\end{array}$ & $\begin{array}{c}\text { Managerial } \\
\text { Technologies }\end{array}$ & OI-1 & OI-2 \\
\hline $\begin{array}{l}\text { Influence of the } \\
\text { government economic } \\
\text { policy }\end{array}$ & -0.026 & 0.018 & $0.079(*)$ & 0.024 & 0.001 \\
\hline $\begin{array}{l}\text { Influence of the local } \\
\text { authorities' policy }\end{array}$ & $0.090(* *)$ & $0.099(* *)$ & 0.041 & 0.032 & $0.085(* *)$ \\
\hline $\begin{array}{l}\text { Influence of } \\
\text { competition }\end{array}$ & $0.080(* *)$ & 0.049 & $0.114(* *)$ & 0.042 & $0.060(*)$ \\
\hline $\begin{array}{l}\text { The presence of the } \\
\text { state as a major owner }\end{array}$ & -0.053 & -0.040 & 0.009 & -0.049 & $-0.088(* *)$ \\
\hline $\begin{array}{l}\text { The presence of } \\
\text { foreign individuals or } \\
\text { legal entities as major } \\
\text { owners }\end{array}$ & 0.021 & $0.163(* *)$ & $0.172(* *)$ & $0.062(*)$ & $0.073(*)$ \\
\hline $\begin{array}{l}\text { Employees of an } \\
\text { enterprise as major } \\
\text { owners }\end{array}$ & 0.047 & -0.024 & -0.054 & 0.003 & 0.029 \\
\hline
\end{tabular}

* - statistically significant at $95 \%$;

$* *$ - statically significant at $99 \%$.

The influence of the economic policy of the Government results in changes in managerial technologies, e.g. leading to the development of new financial schemes and forms of personnel management; otherwise, economic policy is neutral with respect to innovative processes. It was somehow possible to fill this gap by economic programs of the local authorities that restored local production and distribution networks.

The influence of competition is the factor that really brings us closer to international practice (Weiss, 2003) - competition fosters product innovations, changes in management technique and searches for new business partners.

As far as the influence of ownership structure is concerned, neither the employees' ownership of significant stakes in a firm nor state ownership affects the intensity of innovative activities. However, the situation will be different if foreigners own sizeable blocks of shares. The interconnectedness between foreign ownership and high intensity of innovative processes is obvious. Unfortunately, the correlation analysis cannot postulate the cause and effect relations. Transplanting of managerial technologies and other innovations under 
pressure from foreign owners is a generally accepted explanation ${ }^{7}$, but the opposite might also be true: foreign owners acquire enterprises that demonstrate high dynamism of development, including innovation sphere ${ }^{8}$.

Speaking about pressure exerted on an enterprise, we could identify the influence of external owners in a different way, through determining interrelations between innovative processes and the "density of control over enterprise's activities" (see Table 4).

Table 4. Influence of Corporate Dependence on Intensity of Innovative Processes (Average Values of Intensity Parameters by Individual Groups).

\begin{tabular}{|l|c|c|c|c|c|}
\hline Independence of a firm & $\begin{array}{c}\text { Product } \\
\text { innova- } \\
\text { tions }\end{array}$ & $\begin{array}{c}\text { Techno- } \\
\text { logical } \\
\text { innova- } \\
\text { tions }\end{array}$ & $\begin{array}{c}\text { Mana- } \\
\text { gerial } \\
\text { techno- } \\
\text { logies }\end{array}$ & OI-1 & OI-2 \\
\hline $\begin{array}{l}\text { A firm is completely autonomous in its } \\
\text { activities. }\end{array}$ & 3.12 & 2.70 & 7.33 & 1.94 & 3.97 \\
\hline $\begin{array}{l}\text { A firm is a member of an informal group } \\
\text { of enterprises coordinating certain } \\
\text { economic issues. }\end{array}$ & 3.04 & 2.83 & 8.06 & 2.44 & 4.29 \\
\hline $\begin{array}{l}\text { A firm is a component of a major } \\
\text { economic structure that determines } \\
\text { development prospects. }\end{array}$ & 2.94 & 3.18 & 8.25 & 1.91 & 4.14 \\
\hline $\begin{array}{l}\text { A firm is a component of an economic } \\
\text { structure that determines its future and } \\
\text { current development. }\end{array}$ & 2.39 & 2.50 & 8.17 & 1.91 & 3.55 \\
\hline Significance of differences & $99.9 \%$ & $93.3 \%$ & $94.6 \%$ & $63.6 \%$ & $99.3 \%$ \\
\hline
\end{tabular}

The presence of an "external" structure that determines development prospects for a firm bolsters technological innovations. Possibly, the clearer prospects of activities are an incentive for implementing more ambitious projects ${ }^{9}$. If the "density of control" grows to the level of control over operating activities the innovative potential of an enterprise will be drastically reduced. This condition

${ }^{7}$ The management writers currently advocate the liberation of foreign subsidiaries of multinational companies from the pure reproduction of product and process innovations made in the home country (see Birkinshaw/Ridderstrake 1999; Birkinshaw/Hood 2001). The uniformity of management processes within large corporations is still unchallenged.

8 The higher innovativeness of firms with foreign ownership was observed in developed countries as well, e.g. Australia (see Rogers 2000).

9 Or simply the risks connected with technological development in a competitive market are transferred to an external owner. 
is reflected not only in the sphere of new products and distribution channels but also in the sphere of technological development, which is more dangerous. The rigidity of external connections possibly slows down the introduction of "breakthrough technologies". We indicated that these parameters were closely interconnected. Another explanation of this phenomenon is that the strengthening of operating control not only slows down the decision-making processes but also removes the motives to innovate ${ }^{10}$.

\section{Testing of Formulated Hypotheses}

Our system of hypotheses was confirmed. In most cases, changes in intensity of technological and product innovations, indeed, provoke higher intensity of changes in management techniques (Hypothesis 1). At the same time, innovations in managerial techniques provoke internal reorganization of a firm (Hypothesis 2).

High intensity of product and technological changes is connected with higher level of inter-organizational innovations (Hypothesis 3).

As far as the influence of the institutional environment is concerned, it was impossible to identify its structure that clearly provokes intensification of innovative activities (Hypothesis 4). Nevertheless, it is possible to indicate certain elements of such an environment that maximize intensity of all types of innovations:

- A firm is a component of a major economic structure under foreign ownership that determines only the strategic parameters of its development (maximization of technological innovations).

- A firm is subject to significant influence of competition (maximization of managerial technologies, production innovations and intra-firm organizational innovations).

- Local authorities actively support "domestic producers" (maximization of product innovations and inter-firm organizational innovations).

- A firm does not have a substantial stake of state ownership.

Significantly, the development of certain, most dynamic Russian industries (for example the beer industry) confirms the identified configuration of external factors fits exactly the reality.

10 Frequently, incorporation of firms into "dense" business formations completely removes incentives for innovative development. For example, when an enterprise begins to work under "tolling schemes" within integrated business structures it loses all connections with the market and is completely "deprived" of its own financial means for development. 


\section{Innovativeness and Competitiveness}

Having dealt with the structure of innovative activities of Russian enterprises, we can now move to the key issue: interconnections between innovative activities and competitiveness.

At a firm's level, current competitiveness is manifested, first and foremost, in the ability to offer goods of acceptable quality at affordable prices. We would like to emphasize that not only the absolute level of prices and quality that is important but also the price/quality relationship. If a firm manufactures a product that is significantly superior to a product of its competitors in terms of quality, and is capable of setting a high price for such product, this fact will testify to the existence of the whole range of accompanying activities (adequate information of consumers about advantages of this commodity, an appropriate promotion of the brand, control over distribution network, etc.). At the same time, a real competitiveness, i.e. prospective competitiveness, is determined by the ratio between product quality and production costs. High quality combined with low costs also permits price manoeuverability and ensures the ability to generate profit for the development of production and distribution systems.

Thus we chose the parameter of "quality of products and services minus costs" as the most general indicator of a firm's competitiveness. The parameters of "product quality" and "level of costs" for a firm were assessed in comparison with the average level of these variables in the respective industry. As a result of scaling the values of the final parameter, three control values were established:

- high costs and low quality - "bad" mark;

- average quality combined with average specific costs - "average" mark;

- high quality and low costs - "good" mark.

Table 5. Distribution of Intensity of Innovative Activities by Innovative Directions Depending on Competitiveness Parameter (Average Point by Competitiveness Level)

\begin{tabular}{|l|c|c|c|c|c|}
\hline $\begin{array}{c}\text { Parameter } \\
\text { "quality minus costs" }\end{array}$ & $\begin{array}{c}\text { Product } \\
\text { innovation }\end{array}$ & $\begin{array}{c}\text { Techno- } \\
\text { logical } \\
\text { innovation }\end{array}$ & $\begin{array}{c}\text { Managerial } \\
\text { technologies }\end{array}$ & OI-1 & OI-2 \\
\hline Bad & 2.15 & 1.86 & 5.84 & 1.56 & 3.19 \\
\hline Average & 2.78 & 2.65 & 7.69 & 2.00 & 3.87 \\
\hline Good & 3.21 & 3.03 & 8.87 & 2.16 & 4.23 \\
\hline Significance of difference & $99.9 \%$ & $99.9 \%$ & $99.9 \%$ & $95.5 \%$ & $99.9 \%$ \\
\hline
\end{tabular}

There is a clear connection between the intensity of implementation of different innovative processes and the resulting competitiveness. Enterprises with greater 
intensity of innovative activities demonstrate a higher level of competitiveness (see Table 5).

Having proved the general existence of a link between innovativeness and competitiveness, we could begin to solve the main task, i.e. to determine the configuration of innovative activities of a firm that creates conditions for a breakthrough in the level of competitiveness. We conducted a regression analysis to determine which innovations are connected to the greatest extent with the win-win combination of quality and costs. We were able to identify the following types of innovation using regression analysis:

- changes in organizational structure and creation of new structural units (significance of the variable in the regression equation is 0,000 );

- implementation of new remuneration schemes (significances of the variable in the regression equation is 0,020 )

- introduction of ISO standards (significance of the variable in the regression equation is 0,033 );

- application of new methods of project financing (significance of the variable in the regression equation is 0,074 ).

At the same time, there are no significant connections between the intensity of technological and product innovations and a firm's competitiveness.

Therefore the "innovation flexibility" in all spheres of a firm's activities (production, finance, personnel and organizational structure) rather than innovations themselves guarantee strengthening of competitiveness. The role of the organizational structure dynamism turns out to be particularly high. We saw that it was the internal organizational structure that was the most rigid aspect, in particular with respect to product innovations (see Figure 2). Therefore, the adaptation of the organizational structure to technological and product innovations turns out to be the precondition for a firm's superiority over its competitors. Specific forms of changes in the organizational structure could be different, such as the establishment of business units, spin-off of project divisions and reduction of management levels.

We can state that the flexibility of the organizational structure is particularly important not only with respect to the prospective but also with respect to the current competitiveness that is determined by the price/quality relationship. Having tested through regression analysis what innovations affect the win-win price/quality ratio, we could see again only three meaningful variables:

- establishment of new structural units (level of meaningfulness of 0,002);

- introduction of ISO standards (level of meaningfulness of 0,063);

- spin-off of subsidiaries (level of meaningfulness of 0,051). 
Therefore, the "normalization" of production and technological processes with the help of ISO standards and flexible organizational transformation including not only changes in the internal divisions but also its restructuring is the precondition for ensuring stability of the current market position of a firm.

\section{Instead of a Conclusion - General State and Prospects of Innovative Processes in Russian Industry}

The landscape of innovative processes in Russia's industry is quite complex and controversial. We would like to indicate its key pillars:

- Innovative processes continue in the key sectors of Russia's industry. They are more intensive in the sphere of production mix and not too intensive in the sphere of introduction of new technologies.

- Introduction of new products is largely based on the competitive imitation. There are much fewer cases of transfer in the sphere of technology. It means that the infrastructure for technology transfer is inadequate.

- Mastering of new technologies often comes into conflict with the available market infrastructure of an enterprise, i.e. its suppliers and other partners. Radical changes in technology result in the revision of the whole business chain.

- Institutional environment has a very modest effect on the innovative activity of enterprises. In general, the impact of the state economic policy on the intensity of innovative processes is not very visible. At the same time, processes of centralization of business activities within integrated business structures frequently slow down innovations, particularly in technological sphere.

We strongly believe that our results are not limited to Russia and invite other scholars to use our research instruments and implement similar studies in other post-communist countries.

What did our study show? Managerial technologies of Russian enterprises remain quite a dynamic sphere that steadily follows product and technological innovations. Therefore lagging behind in managerial technologies by itself cannot be seen as the reason for the continuing low level of technology transfer. That is to say the system of technology transfer that existed during the Soviet period, with all its drawbacks, was completely eliminated, while modern forms of technology transfer were not created. Technology transfer remains a "point" process and in most cases embraces just one enterprise that has to completely replace its business partners in the case of radical changes in technology. As far as institutional conditions are concerned, their influence is small and cannot be considered a serious obstacle to the innovation process. 
It is the rigidity of the existing organizational structures of Russian companies that really slows down both the innovative process as such and the implementation of its results in the form of enhanced competitiveness of companies. On the one hand, innovations cannot break through the "thickness" of multi-level hierarchical systems and pass through a multitude of approvals. On the other hand, innovations themselves are implemented within the existing structures, i.e. within the accepted procedure of distribution of functions and resources. In many cases, this fact does not permit to achieve a desired effect of innovations.

Is it possible to overcome the rigidity of structures of Russian companies? We believe that the rigidity of organizational structures is in many cases a consequence of social, rather than technological conditions. Simply speaking, the greater trust exists between top management and mid-level management the more flexible and adaptive could the organizational structure of the firm be. This mutual trust will be created if the parameters for distribution of the effect from the firm's activities, in particular from innovative activities, are coordinated at least in an operating regime. It means that the creation of new forms of motivation becomes the key issue of enhancing competitiveness of Russian firms.

\section{References}

Abernathy, W.J./Utterback, J.M. (1978): Patterns of Industrial Innovation. Technology Review, June/July, 40-49.

Barras, R. (1990): Interactive Innovation in Financial and Business Services: The Vanguard of the Service Revolution. Research Policy, 19, 215-237.

Barras, R. (1986): Towards a Theory of Innovation in Services. Research Policy, 15, 161-173.

Brocas, I. (2003): Vertical Integration and Incentives to Innovate. International Journal of Industrial Organization, 21 ( 4), 457-489, 2003.

Burkinshaw, J./Hood, N. (2001): Unleash Innovation in Foreign Subsidiaries. Harvard Business Review, March, 131-139.

Birkinshaw, J./Ridderstrake, J. (1999): Fighting the Corporate Immune System: A Process Study of Subsidiary Initiatives in Multinational Corporations, International Business Review, 8 (2), 149-180.

Daft R.L. (1978): A Dual-Core Model of Organizational Innovation. Academy of Management Journal, 21, 193-210.

Damanpour, F. (1991): Organizational Innovation: A Meta-Analysis of Effects of Determinants and Moderators. Academy of Management Review, 34 (3), 555-590.

Damanpour, F. (1987): The Adoption of Technological, Administrative and Ancillary Innovations: Impact of Organizational Factors. Journal of Management, Vol. 13, 675688 . 
Damanpour, F./Evan, W.M. (1984): Organizational Innovation and Performance: The Problem of "Organizational Lag". Administrative Science Quarterly, Vol. 29, 392-409.

Doz, Y./Thanheiser, H. (1993): Regaining Competitiveness: A process of Organizational Renewal, In: Hendry, J./Johnson, G. (eds.): Strategic Thinking: Leadership and the Management of Change, New York: John Wiley \& Sons.

Evan, W.M. (1966): Organizational Lag. Human Organizations, Vol. 25, 51-53.

Frambach, R.T./Schillewaert, N. (2002): Organizational Innovation Adoption A Multi-level Framework of Determinants and Opportunities for Future Research. Journal of Business Research, 55 (2), 163-176.

Gopalakrishnan, S./Bierly, P./Kessler, E.H. (1999): A Reexamination of Product and Process Innovations using a Knowledge-based View. Journal of High Technology Management Research, 10 (1), 147-166.

Gopalakrishnan, S./Damanpour, F.A (1997): Review of Innovation Research in Economics, Sociology and Technology Management. Omega: The International Journal of Management Science, 25 (1), 15-28.

Gurkov, I. (2004): Business Innovation in Russian Industry. Post-Communist Economies, 16 (4), 423-438.

Maital, S. (2000): The Relation Between Perceived Innovativeness and Profitability, In: Grupp, H./Maital S.: Managing the New Product Development and Innovation. Haifa: The Samuel Neaman Institute.

Mighly, D.F./Dowling, G.R. (1978): Innovativeness: The Concept and its Measurement. Journal of Consumer Research, 4, 229-242.

Myers S./Marquis D.L. (1969): Successful Industrial Innovation. Washington: D.C., National Science Foundation.

Normann R. (1971): Organizational Innovativeness: Product Variation and Reorientation, Administrative Science Quarterly, 16, 203-215.

OECD (2002): Dynamising National Innovation Systems. Paris: OECD.

Rogers, M. (2000): Understanding Innovative Firms. An Empirical Analysis of the GAPS. May, Melburn Institute Working Paper No. 8.

Teece, D.J. (ed.) (1987): The Competitive Challenge: Strategies for Industrial Innovation and Renewal. Cambridge: MA Ballinger.

Tidd J./Bessant J./Pavitt K. (2001): Managing Innovation: Intergrating Technological, Market and Organizational Change. 2nd ed., New York: Wiley.

Tushman M.L./Anderson P. (eds.) (1997): Managing Strategic Innovation and Change. New York: Oxford University Press.

Tushman M.L., O’Reilly C.A. III (1997): Winning Through Innovation. Boston: Harvard Business School Press.

Utterback, J./Abernathy, W.A (1975): Dynamic Model of Process and Product Innovation. Omega, 3, 639-656.

Vasin V.A., Mindeli L.E. (2002): National Innovative System: Premises and Mechanisms of Functioning. Moscow: TsISN. 
Weiss, P. (2003): Adoption of Product and Process Innovations in Differentiated Markets: The Impact of Competition. Review of Industrial Organization; 23 (3/4), 301-315.

\section{Questionnaire on innovations (translated from Russian)}

\section{Q1. Areas of operations of your firm (please, select the main areas)?}

\begin{tabular}{|l|c|}
\hline Extracting & 1 \\
\hline Energy & 2 \\
\hline Timber & 3 \\
\hline Chemicals and pharmaceuticals & 4 \\
\hline Metallurgy & 5 \\
\hline Machine-tools & 6 \\
\hline Electronics & 7 \\
\hline Food-processing & 8 \\
\hline Textile & 9 \\
\hline Building & 10 \\
\hline Agriculture & 11 \\
\hline Retail and catering & 12 \\
\hline Wholesale & 13 \\
\hline Informatics & 14 \\
\hline Education and science & 15 \\
\hline Housing services & 16 \\
\hline Finance and insurance & 17 \\
\hline Transportation & 18 \\
\hline Others & 19 \\
\hline
\end{tabular}

Q2. The average number of personnel in 2002?

\begin{tabular}{|l|l|}
\hline Less than 20 & 1 \\
\hline $20-50$ & 2 \\
\hline $51-100$ & 3 \\
\hline $101-500$ & 4 \\
\hline $501-1000$ & 5 \\
\hline $1001-3000$ & 6 \\
\hline More than 3000 & 7 \\
\hline Difficult to say & 8 \\
\hline
\end{tabular}

\section{Q3. Sales in 2001?}

\begin{tabular}{|l|l|}
\hline Less than 1 mio. Rubles & 1 \\
\hline $1-10$ & 2 \\
\hline $10-50$ & 3 \\
\hline $50-200$ & 4 \\
\hline
\end{tabular}




\begin{tabular}{|l|l|}
\hline $200-500$ & 5 \\
\hline More than 500 & 6 \\
\hline Difficult to say & 7 \\
\hline
\end{tabular}

\section{Q4. Current capacity utilization level?}

\begin{tabular}{|l|c|}
\hline Very low & 1 \\
\hline Low & 2 \\
\hline Normal & 3 \\
\hline Excessive & 4 \\
\hline Difficult to say & 5 \\
\hline
\end{tabular}

\section{Q5 . What is current orders backlog?}

\begin{tabular}{|l|c|}
\hline Very low & 1 \\
\hline Low & 2 \\
\hline Normal & 3 \\
\hline Excessive & 4 \\
\hline Difficult to say & 5 \\
\hline
\end{tabular}

Q6. Average age of the main technological equipment?

\begin{tabular}{|l|l|}
\hline Less than 3 years & 1 \\
\hline 3-7 years & 2 \\
\hline $7-15$ years & 3 \\
\hline More than 15 years & 4 \\
\hline Difficult to say & 5 \\
\hline
\end{tabular}

Q7. Your company is:

\begin{tabular}{|l|l|}
\hline State enterprise & 1 \\
\hline Privatized company & 2 \\
\hline Private from the beginning & 3 \\
\hline Joint venture & 4 \\
\hline Another form & 5 \\
\hline Difficult to say & 6 \\
\hline
\end{tabular}

Q8. Are among the owners with a share of $25 \%$ of the stock or more?

\begin{tabular}{|l|c|}
\hline The state & 1 \\
\hline Employees & 2 \\
\hline Foreigners & 3 \\
\hline Difficult to say & 4 \\
\hline
\end{tabular}

Q9. What is the current economic situation of your firm?

\begin{tabular}{|l|c|}
\hline Bad & 1 \\
\hline Satisfactory & 2 \\
\hline
\end{tabular}




\begin{tabular}{|l|l|}
\hline Good & 3 \\
\hline Difficult to say & 4 \\
\hline
\end{tabular}

Q10. How has the economic situation changed over the past two years?

\begin{tabular}{|l|l|}
\hline Much worse & 1 \\
\hline Some worse & 2 \\
\hline No change & 3 \\
\hline Some better & 4 \\
\hline Much better & 5 \\
\hline Difficult to say & 6 \\
\hline
\end{tabular}

Q11*. Change in personnel number over the past two years?

\begin{tabular}{|l|c|}
\hline Much decreased & 1 \\
\hline Some decrease & 2 \\
\hline No change & 3 \\
\hline Some increase & 4 \\
\hline Significant increase & 5 \\
\hline Difficult to say & 6 \\
\hline
\end{tabular}

Q12*. Level of wages and salaries by comparison to neighbor companies?

\begin{tabular}{|l|c|}
\hline Much lower & 1 \\
\hline Some lower & 2 \\
\hline The same & 3 \\
\hline Some higher & 4 \\
\hline Much higher & 5 \\
\hline Difficult to say & 6 \\
\hline
\end{tabular}

Q13*. Level of perks and benefits?

\begin{tabular}{|l|l|}
\hline Much lower & 1 \\
\hline Some lower & 2 \\
\hline The same & 3 \\
\hline Some higher & 4 \\
\hline Much higher & 5 \\
\hline Difficult to say & 6 \\
\hline
\end{tabular}

\section{Q14*. Main goals of top managers?}

\begin{tabular}{|l|l|}
\hline High quality & 1 \\
\hline Maintaining employment & 2 \\
\hline High wages & 3 \\
\hline Value maximization & 4 \\
\hline Prosperity of Russia & 5 \\
\hline Oversea expansion & 6 \\
\hline
\end{tabular}




\begin{tabular}{|l|c|}
\hline Reputation maintaining & 7 \\
\hline Local expansion & 8 \\
\hline Other & 9 \\
\hline Difficult to say & 10 \\
\hline
\end{tabular}

\section{Q15. How imminent are the following problems?}

Not at all 1_2_3_4_5 Extremely

\begin{tabular}{|c|c|c|c|c|}
\hline Excess of staff & 12 & 3 & 4 & \\
\hline Shortage of staff & 12 & 3 & 4 & 5 \\
\hline Low capacity utilization & 122 & 3 & 4 & 5 \\
\hline High credit endebtness & 122 & 3 & 4 & 5 \\
\hline High debit endebtness & $1 \quad 2$ & 3 & 4 & 5 \\
\hline Unpaid taxes & 122 & 3 & 4 & 5 \\
\hline Conflicts within the top management & $1 \_2$ & 3 & 4 & 5 \\
\hline Conflicts between management and owners & 122 & 3 & 4 & 5 \\
\hline Conflicts between owners & $1 \quad 2$ & 3 & 4 & 5 \\
\hline Conflicts between management and workers & 1 & 3 & 4 & 5 \\
\hline Other problems (specify) & 1 & 3 & 4 & 5 \\
\hline
\end{tabular}

Q16*. How independent is your firm?

\begin{tabular}{|l|c|}
\hline Absolutely & 1 \\
\hline We are part of an informal group & 2 \\
\hline $\begin{array}{l}\text { We are a part of a corporation which determines our strategic } \\
\text { development }\end{array}$ & 3 \\
\hline $\begin{array}{l}\text { We are a part of a corporation which determines our operating } \\
\text { decisions }\end{array}$ & 4 \\
\hline Other & 5 \\
\hline Difficult to say & 6 \\
\hline
\end{tabular}

\section{Q17*. What are the relations with local authorities?}

\begin{tabular}{|l|c|}
\hline They help us seriously & 1 \\
\hline They help us sometimes & 2 \\
\hline No interactions & 3 \\
\hline Some excessive regulations & 4 \\
\hline Deep conflict & 5 \\
\hline Other & 6 \\
\hline Difficult to say & 7 \\
\hline
\end{tabular}

\section{Q18. What is the influence of _ ?}

Extremely $-3 \_-2 \_1 \_0 \_1 \_2 \_3$ Extremely negative Positive 


\begin{tabular}{|c|c|c|c|c|c|}
\hline Government economic policy & $-3-2$ & $1 \quad 0$ & 1 & 2 & 3 \\
\hline Competition & $-3-2$ & $1 \ldots 0$ & 1 & 2 & 3 \\
\hline Banks & $-3-2$ & 1 & 1 & 2 & 3 \\
\hline Owners & $-3-2$ & 1 & 1 & 2 & 3 \\
\hline Suppliers & $-3-2$ & 1 & 1 & 2 & 3 \\
\hline Customers & -3 & 1 & 1 & 2 & 3 \\
\hline Local authorities & $-3-2$ & 1 & 1 & 2 & 3 \\
\hline Current political situation & -3 & 1 & 1 & 2 & 3 \\
\hline
\end{tabular}

Q19. To which extent may you retrace changes in ?

Not at all 1_2_3_4_5 Completely

\begin{tabular}{|c|c|c|c|c|}
\hline Economic policy & $1 \quad 2$ & 3 & 4 & 5 \\
\hline Competitive situation & 12 & 3 & 4 & 5 \\
\hline Banks' behavior & $1 \ldots 2$ & 3 & 4 & 5 \\
\hline The structure of ownership & $1 \_2$ & 3 & 4 & 5 \\
\hline Behavior of owners & $1 \_2$ & 3 & 4 & 5 \\
\hline Behavior of suppliers & 1 & 3 & 4 & 5 \\
\hline Behavior of customers & 122 & 3 & 4 & 5 \\
\hline Behavior of local authorities & $1 \ldots 2$ & 3 & 4 & 5 \\
\hline Political situation & $1 \_2$ & 3 & 4 & 5 \\
\hline
\end{tabular}

Q20. Compare the characteristics of your production (services) with that of direct competitors.

Much worse $1 \_2 \_3 \_4 \_5$ Much better

\begin{tabular}{|l|l|}
\hline Costs & $1 \_2 \_3 \_4 \_5$ \\
\hline Technology & $1 \_2 \_3 \_4 \_5$ \\
\hline Technological culture & $1 \_2 \_3 \_4 \_5$ \\
\hline Price & $1 \_2 \_3 \_4 \_5$ \\
\hline Quality & $1 \_2 \_3 \_4 \_5$ \\
\hline Marketing channels & $1 \_2 \_3 \_4 \_5$ \\
\hline Trademark recognition & $1 \_2 \_3 \_4 \_5$ \\
\hline
\end{tabular}

\section{Q21. What is the position on your markets?}

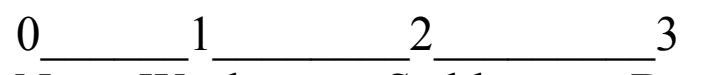

\begin{tabular}{l|l|} 
No Weak Stable Dominate & \\
\hline Local producers & $0 \_1 \_2 \_3$ \\
\hline Local subsidiaries of foreign companies & $0 \_1 \_2 \_3$ \\
\hline Developed countries & $0 \_1 \_2 \_3$ \\
\hline Developing countries & $0 \_1 \_2 \_3$ \\
\hline Eastern Europe and the former USSR & $0 \_1 \_2 \_3$ \\
\hline Other & $0 \_1 \_2 \_3$ \\
\hline
\end{tabular}




\section{Q22. Did the following events happen in 1999-2000?}

$0-$ No

1 - In minimal extend

2 - In some extend

3 - In great extend

Completely new products in the traditional sphere

Diversification into new spheres of activities

Mastering new technology

New methods for quality control

Mastering foreign accounting standards

Mastering new management accounting

New financing methods

New Russian business partners

New foreign partners

New marketing channels

New recruiting forms

New performance appraisal

New remuneration schemes

New departments

Spin-offs

Purchase of other firms

$0 \_1 \_2 \_3$

$\begin{array}{llllllll}0 & 1 & 2 & 3\end{array}$

$0 \_1 \_2 \_3$

$0 \_1223$

$0+123$

$0 \_1$ 2_ 3

$\begin{array}{lllllllllll}0 & 1 & 2 & 3\end{array}$

$0 \_1 \_2 \_3$

$0 \_1 \_23$

$0 \_1 \_23$

$\begin{array}{llllllllll}0 & 1 & 2 & 3\end{array}$

$0 \_1 \_2 \_3$

$0 \_1 \_2 \ldots 3$

$\begin{array}{llllllllll}0 & 1 & 2 & 3\end{array}$

$0 \_1 \_23$

$0 \_1 \_23$

\section{Q23*. What were the sources of innovative ideas?}

\section{Q23.1 In technology}

\begin{tabular}{|l|l|}
\hline No ideas & 0 \\
\hline In-house development & 1 \\
\hline Contract development & 2 \\
\hline Purchase of licenses & 3 \\
\hline Cooperation with similar producers & 4 \\
\hline Foreign partners & 5 \\
\hline Other & 6 \\
\hline
\end{tabular}




\section{Q23.2 In new products and marketing}

\begin{tabular}{|l|l|}
\hline No new ideas & 0 \\
\hline Own invention & 1 \\
\hline From new employees & 2 \\
\hline From consultants & 3 \\
\hline From customers & 4 \\
\hline From fairs and exhibitions & 5 \\
\hline From contacts with similar producers & 6 \\
\hline From foreign partners & 7 \\
\hline Other & 8 \\
\hline
\end{tabular}

Q24. How difficult are the following actions in new product development and market launch?

0 - Not applicable

1 - Easy

2 - Moderately difficult

3 - Very difficult

\begin{tabular}{|l|l|}
\hline Financing of a new project & $0 \_1 \_2 \_3$ \\
\hline Access to technology & $0 \_1 \_2 \_3$ \\
\hline Staffing & $0 \_1 \_2 \_3$ \\
\hline Changes of job specifications & $0 \_1 \_2 \_3$ \\
\hline Cooperation between departments & $0 \_1 \_2 \_3$ \\
\hline Innovation budgeting and control & $0 \_1 \_2 \_3$ \\
\hline Clarification of desired users' specifications & $0 \_1 \_2 \_3$ \\
\hline Product design & $0 \_1 \_2 \_3$ \\
\hline Reaching the necessary quality level & $0 \_1 \_2 \_3$ \\
\hline Maintaining the technological culture & $0 \_1 \_2 \_3$ \\
\hline Tuning with suppliers & $0 \_1 \_2 \_3$ \\
\hline Pricing for a new product & $0 \_1 \_2 \_3$ \\
\hline Understanding with competitors & $0 \_1 \_2 \_3$ \\
\hline Licensing and certification & $0 \_1 \_2 \_3$ \\
\hline Advertising campaign & $0 \_1 \_2 \_3$ \\
\hline Mastering distribution channels & $0 \_1 \_2 \_3$ \\
\hline Contacts with informal structures & $0 \_1 \_2 \_3$ \\
\hline
\end{tabular}

Q25*. What may the investment attractiveness of your company be?

\begin{tabular}{|l|c|}
\hline High quality & 1 \\
\hline High demand & 2 \\
\hline High profitability & 3 \\
\hline Unique technologies & 4 \\
\hline Qualified labour fource & 5
\end{tabular}




\begin{tabular}{|l|c|}
\hline Good political connections & 6 \\
\hline Foreign connections & 7 \\
\hline Good distribution network & 8 \\
\hline Good location & 9 \\
\hline High value of land & 10 \\
\hline High value of production facilities & 11 \\
\hline Good trademark & 12 \\
\hline High value growth potential & 13 \\
\hline Other & 14 \\
\hline
\end{tabular}

Q26*. What has the level of cumulative investments been over the past two years?

\begin{tabular}{|l|l|}
\hline No investments & 1 \\
\hline $5 \%$ of fixed assets & 2 \\
\hline $5-10 \%$ of fixed assets & 3 \\
\hline $10-20 \%$ & 4 \\
\hline More than $20 \%$ & 5 \\
\hline Difficult to say & 6 \\
\hline
\end{tabular}

Q27*. What have the main sources of investments been?

\begin{tabular}{|l|c|}
\hline Amortization funds & 1 \\
\hline Retained earnings & 2 \\
\hline Long-term credits & 3 \\
\hline Stock issues & 4 \\
\hline Bond issues & 5 \\
\hline State credits & 6 \\
\hline State grants & 7 \\
\hline Foreign grants & 8 \\
\hline Local investments & 9 \\
\hline Foreign investments & 10 \\
\hline Other & 11 \\
\hline
\end{tabular}

\section{Q28*. What were the main directions of investments?}

\begin{tabular}{|l|l|}
\hline Modernization of technological equipment & 1 \\
\hline Purchase of new equipment & 2 \\
\hline Purchase of licenses and know-how & 3 \\
\hline Purchase of specialists & 4 \\
\hline Development of dealers' network & 5 \\
\hline Purchase or construction of new facilities & 6 \\
\hline Purchase of other companies & 7 \\
\hline Other & 8 \\
\hline
\end{tabular}


Q29*. Which organizational forms have you used for mastering innovations?

\begin{tabular}{|l|l|}
\hline Temporary functional groups & 1 \\
\hline Temporary cross-functional groups & 2 \\
\hline Temporary departments & 3 \\
\hline Establishing subsidiaries & 4 \\
\hline Joint ventures with other companies & 5 \\
\hline Other forms & 6 \\
\hline
\end{tabular}

Q30. Gender

Male - 1

Female - 2

Q31. Age

Q32. Total connection with the present employer years

Q33. Length of service in the present position years 